\title{
Перший досвід перфорації клапана легеневої артерії з одномоментним стентуванням артеріальної протоки у пацієнтів 3 атрезією клапана легеневої артерії та інтактною міжшлуночковою перегородкою
}

\author{
Максименко А. В., Кузьменко Ю. Л., Довгалюк А. А., Мотречко О. О., Вітовська О. Р.
}

ДУ «Науково-практичний медичний центр дитячої кардіології та кардіохірургії МОЗ України» (Київ)

\begin{abstract}
Атрезія клапана легеневої артерії з інтактною міжшлуночковою перегородкою (АЛА з ІМШП) - комплексна вроджена вада серця, яка характеризується атрезією клапана із супутньою гіпоплазією правого шлуночка (ПШ) та тристулкового клапана різного ступеня вираженості з дуктус-залежним легеневим кровотоком. Одним із сучасних методів лікування цієї вади є перфорація клапана легеневої артерії з подальшим стентуванням відкритої артеріальної протоки (ВАП).

Мета роботи - висвітлити перший досвід перфорації клапана ЛА з одномоментним стентуванням артеріальної протоки у пацієнтів з АЛА з ІМШП.

Матеріали та методи. На базі ДУ «НПМЦДКК МОЗ України» трьом новонародженим з АЛА і ІМШП було виконано одномоментну перфорацію клапана ЛА зі стентуванням ВАП.

Результати та обговорення. Процедура була успішно проведена трьом новонародженим пацієнтам із помірною гіпоплазією ПШ з мембранозною атрезією клапана ЛА з ІМШП. У середньому після втручання пацієнти перебували у ВРІТ протягом 5 діб, двоє з них потребували ШВЛ, один - симпатоміметичної підтримки. Пацієнтів виписано в середньому на 13-ту добу. Післяопераційних ускладнень не спостерігалось. Ранньої летальності не було.

Висновки. Перфорація клапана ЛА з одномоментним стентуванням ВАП $є$ ефективним і безпечним методом для оптимізації легеневого кровотоку у пацієнтів з АЛА з ІМШП з помірною гіпоплазією ПШ.
\end{abstract}

Ключові слова: атрезія легеневої артерії, перфорація клапана легеневої артерії, стентування ВАП.

Атрезія клапана легеневої артерії з інтактною міжшлуночковою перегородкою (АЛА з ІМШП) - комплексна вроджена вада серця, яка характеризується атрезією клапана із супутньою гіпоплазією правого шлуночка (ПШ) та тристулкового клапана (ТК) різного ступеня вираженості з дуктус-залежним легеневим кровотоком. Новонароджені із цією вадою потребують інфузії простагландину Е1 (ПГЕ1), стабілізації та створення антеградного кровотоку. Операцією вибору при анатомічних варіантах із невеликою та помірною гіпоплазією правих відділів серця є перфорація клапана легеневої артерії (ЛА) [1, 6]. У випадку, якщо після створення антеградного кровотоку двошлуночкова фізіологія досягається не відразу, необхідне створення додаткового джерела кровотоку в ЛА шляхом довготривалої інфузії ПГЕ1 або накладанням модифікованого анастомозу Блелок-Тауссіг [4]. Інфузія ПГЕ1 потребує постійного моніторингу та спостереження в палаті інтенсивної терапії для контролю сатурації крові та попередження ускладнень, оскільки можуть спостерігатись явища обкрадання системного кровотоку при артеріальній протоці великого діаметра та прояви серцевої недостатності. Крім цього, пролонгований період інфузії простагландинів не завжди дозволяє до- сягти достатнього відновлення функції ПШ і уникнути додаткових втручань. Альтернативою хірургічному втручанню або інфузії простагландину Е1 після створення антеградного кровотоку в ЛА $є$ стентування артеріальної протоки.

Мета роботи - висвітлити перший досвід перфорації клапана ЛА з одномоментним стентуванням артеріальної протоки у пацієнтів з АЛА з ІМШП.

Матеріали та методи. На базі ДУ «НПМЦДКК МОЗ України» трьом новонародженим з АЛА і ІМШП було виконано одномоментну перфорацію клапана ЛА зі стентуванням артеріальної протоки.

Перший пацієнт (іст. хвороби № 3118, 2017 р.), вагою 2,5 кг, був госпіталізований у перші години життя. Відразу розпочато інфузію ПГЕ1. При госпіталізації сатурація киснем артеріальної крові 80\%. За даними ехокардіографічного обстеження (ЕхоКГ) встановлено діагноз: АЛА з ІМШП, помірна гіпоплазія ПШ, дисплазія та помірна недостатність ТК, вторинний дефект міжпередсердної перегородки, ВАП, дрібні коронарно-правошлуночкові фістули (не значимі). Відсутня трабекулярна частина ПШ, співвідношення ПШ/ЛШ 0.74 , верхівка серця сформована лівим шлуночком. ТК діаметром 10 мм (Z-score -1,12). Пацієнту було вико- 
A

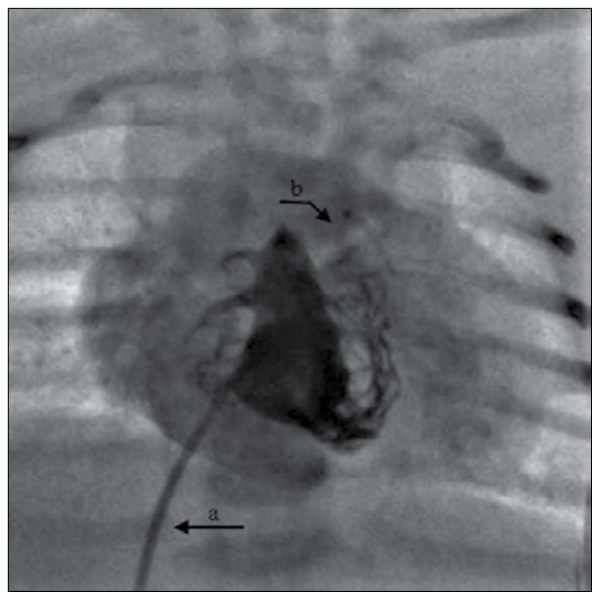

B

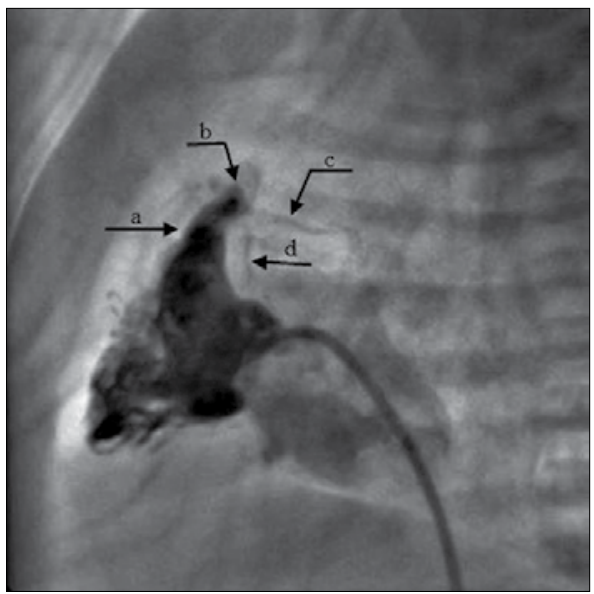

Рис. 1. Гіпоплазований правий шлунок із правошлуночково-лівокоронарною фістулою.

A - права вентрикулографія в прямій проекції: a - катетер заведено через нижню порожнисту вену та праве передсердя в правий шлуночок; $\mathbf{b}$ - правошлуночково-лівокоронарна фістула;

В - права вентрикулографія в боковій проекції: a - вихідний тракт ПШ; $\mathbf{b}$ - клапан ЛА; с - огинаюча коронарна артерія; $\mathbf{d}$ - передня низхідна артерія

нано зондування порожнин серця в першу добу. Тиск у ПШ становив 160/1(9) мм рт. ст. Візуалізовано правошлуночково-лівокоронарну фістулу (рис. 1), ліва коронарна артерія задовільно заповнювалась антеградно. Проведено перфорацію клапана ЛА коронарним провідником ASAHI Miracle 12 та балонну вальвулопластику клапана ЛА коронарним балон-катетером № 1,5 мм, Tyshak II № 4 та Tyshak II № $8 \times 20$ мм послідовно. 3 огляду на різку гіпоплазію ПШ вирішено провести стентування ВАП довжиною 20 мм, діаметром 2,7 мм з боку легеневої артерії, 5,5 мм - 3 боку аорти. Виконано стентування ВАП стент-системою
Ryujn Plus 3,5х22 мм. Стент роздуто з тиском 8 атм. до діаметра 3,4 мм. Нижче наведено ангіограму до і після стентування ВАП (рис. 2). Пацієнт перебував у відділенні реанімації та інтенсивної терапії (BPIT) протягом 140 год., з них 52 год. - на штучній вентиляції легень (ШВЛ) без симпатоміметичної підтримки. Сатурація крові до процедури становила $78 \%$, після - 90\%. Пацієнта було виписано зі стаціонару на 14-ту добу після проведення процедури. При наступній консультації через 3 місяці сатурація становила $82 \%$. За даними ЕхоКГ, кровотік через стент візуалізовано діаметром 3 мм, TK -11 мм $(Z$-score $=-1,49)$.
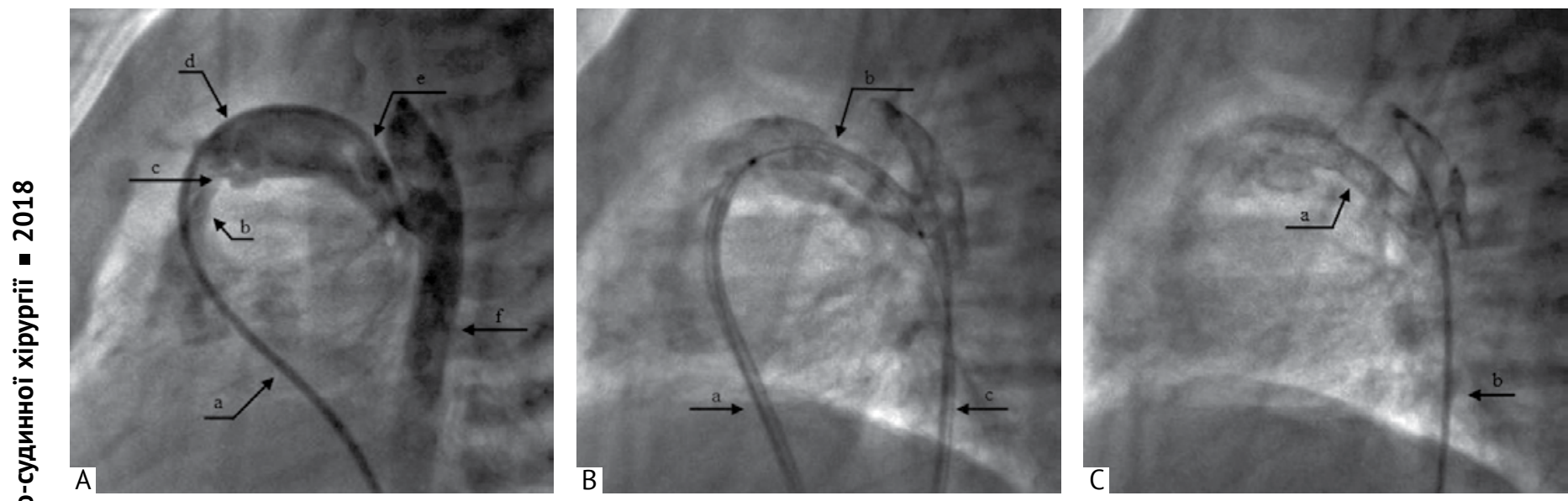

Рис. 2. Рентген-ендоваскулярне стентування ВАП (бокова проекція) після перфорації клапана легеневої артерії в пацієнта з АЛА з ІМШП:

А - контрастування ВАП до стентування: а - катетер заведено ретроградно через нижню порожнисту вену, праве передсердя, правий шлуночок, ВАП у низхідну аорту; b - вихідний тракт ПШ; с - клапан ЛА; d - стовбур ЛА; е - ВАП; $\mathbf{f}$ - низхідна аорта; В - візуалізація стента після роздуття балона (балон-катетер заведено по провіднику, що формує транскардіальну петлю): a - направляючий катетер; $\mathbf{b}$ - транскардіальна петля; c -катетер у низхідній аорті;

C - контрольна ангіографія для оцінки розташування та прохідності стента: a - стент у ВАП; $\mathbf{b}$ - катетер у низхідній аорті 
Другий новонароджений (іст. хвороби № 4030, 2017 р.), вагою 3,5 кг, госпіталізований на 2-гу добу. Діагноз було встановлено пренатально. За даними ЕхоКГ підтверджено діагноз: АЛА з ІМШП, помірна гіпоплазія ПШ та ТK, помірна недостатність TK без порушення гемодинаміки. Порожнина ПШ зменшена за рахунок вираженої гіпертрофії стінок ПШ, скоротливість значно знижена, ТК діаметром $7,5$ мм (z-score $=-3,09)$. При зондуванні тиск у ПШ 75/1(10). Після проведення правої вентрикулографії - ПШ гіпоплазований, складається з трьох частин. Проведено перфорацію клапана ЛА коронарним провідником ASAHI Miracle 12 та балонну вальвулопластику клапана ЛА б. к. № 2,5 мм довжиною 15 мм та MiniTyshak № 9 послідовно. 3 огляду на різку гіпоплазію ПШ проведено стентування ВАП з боку легеневої артерії діаметром 2,7 мм, з боку аорти - 5,5 мм, довжиною 13 мм стент-системою Integriti $3,5 \times 15$ мм. Стент роздуто з тиском 9 атм. до діаметру 3,45 мм. Процедуру було проведено на самостійному диханні, пацієнт перебував у ВРІТ протягом 120 год. Сатурація крові до процедури становила $73 \%$, після $-85 \%$. Пацієнта було виписано зі стаціонару на 14-ту добу після операції. При наступній консультації через 1 місяць сатурація становила 82\%. За даними ЕхоКГ, стент займає типове положення, діаметр внутрішнього просвіту -3 мм, TK -11 мм $(Z$-score $=-1,39)$.

Третій пацієнт (іст. хвороби № 29, 2018 р.), вагою 2,660 кг, народився на 38-му тижні вагітності. Госпіталізований на першу добу після народження КШД з пологового будинку. Діагноз запідозрено постнатально в пологовому будинку. Одразу розпочато інфузію ПГЕ1. При госпіталізації сатурація крові становила 86\%. За даними ЕхоКГ встановлено діагноз: АЛА 3 ІМШП, виражена гіпоплазія ПШ та ТК, виражена тристулкова недостатність, двостулковий аортальний клапан, вторинний дефект міжпередсердної перегородки, ВАП. Клапан ЛА тристулковий, виражений фіброз, гемо динамічно - атрезія, діаметр клапана 9 мм. ТК діаметром 7 мм $(Z$-score $=-3,1)$. Тиск у порожнині ПШ - 100 мм рт. ст. (при системному 60/40). На 2-гу добу життя пацієнту проведено рентген-хірургічне обстеження серця і магістральних судин. Тиск у ПШ - 100/0 (10). При правій вентрикулографії ПШ складається з трьох частин, трабекулярна частина різко гіпоплазована. Пацієнту виконано перфорацію клапана ЛА коронарним провідником MIRACLE 0.014 та вальвулопластику клапана ЛА балоном-катетером MiniTyshak № 4 та Tyshak II “Numed” № 7. 3 огляду на підтверджену після ангіографічного обстеження помірну гіпоплазію правих відділів серця і необхідність створення додаткового кровотоку в ЛА виконано стентування ВАП діаметром з боку аорти 5,8 мм, з боку легеневої артерії - 2,3 мм, довжиною
12 мм системою CHROMA 3x14 мм, стент роздуто 3 тиском 14 атм. до діаметру 3,3 мм. Пацієнт перебував у ВРІТ 124 год., з них 67 год. - на ШВЛ із симпатоміметичною підтримкою (допмін 5 мкг/кг/хв. протягом 4 діб). На 11-ту добу після операції пацієнта виписано зі стаціонару в задовільному стані. Сатурація при виписці 90\%. При наступній консультації через 1,5 місяці після процедури сатурація становила $93 \%$. За даними ЕхоКГ кровотік через стент без обструкції, внутрішній просвіт - 3,3 мм. Тристулковий клапан діаметром 9,5 мм (z-score $=-1.96)$.

Результати та обговорення. Тактика лікування пацієнтів з АЛА з ІМШП залежить від ступеня гіпоплазії правих відділів серця, наявності значимих правошлуночково-коронарних фістул або правошлуночково-залежного коронарного кровотоку [1, 5]. Пацієнтам із невеликою та помірною гіпоплазією ПШ з мембранозною атрезією клапана ЛА показана перфорація клапана ЛА. Помірна гіпоплазія правих відділів серця характеризується TK із Z-score від $-2,5$ до -4,5-5 i/або індексом ТK/МK від 0,5 до 0,75 , а також ПШ, який має притічну частину, добре розвинений вихідний тракт з клапанною атрезією та гіпоплазовану апікальну трабекулярну частину. Відразу після перфорації можуть зберігатись гіпоксемія та розлади гемодинаміки, що зумовлено недостатнім розміром і комплаєнсом ПШ, а також можливою залишковою обструкцією виходу із правого ПШ на клапанному або підклапанному рівні. У такому випадку рекомендується виконання стентування артеріальної протоки одночасно з перфорацією клапана ЛА [1].

В нашому центрі перфорація клапана ЛА з одномоментним стентуванням артеріальної протоки була успішно проведена трьом новонародженим пацієнтам із помірною гіпоплазією ПШ з мембранозною атрезією клапана ЛА з ІМШП. За даними ЕхоКГ та ангіографії, у всіх пацієнтів ПШ складався з трьох частин: притічної, інфундибулярної та гіпоплазованої трабекулярної частин, ТK з z-score до $-3,1$. Один пацієнт мав не значиму правошлуночково-лівокоронарну фістулу. Інфузія ПГЕ1 припинялась перед процедурою. В післяопераційному періоді у ВРІТ всі пацієнти отримували інфузію гепарину з розрахунку 10 ОД/кг/год. Час згортання крові утримувався в межах 10-12 хвилин. При необхідності додатково вводився гепарин 30-50 ОД/кг внутрішньовенно болюсно. Після процедури призначався аспірин 3 розрахунку 5 мг/кг на добу для постійного прийому. Одному пацієнту, у зв'язку з тромбоцитопенією в післяопераційному періоді, аспірин замінено на плавікс 3 розрахунку 0,2 мг/кг на добу. Сатурація крові після процедури 85-90\%. В середньому після втручання пацієнти перебували у ВРІТ протягом 5 діб, двоє 
з них потребували ШВЛ, один - симпатоміметичної підтримки. Пацієнтів виписано в середньому на 13ту добу. Післяопераційних ускладнень не спостерігалось. Ранньої летальності не було.

За нашим досвідом і досвідом інших авторів [2, 4], стентування артеріальної протоки є обгрунтованою альтернативою модифікованому анастомозу БлелокТауссіг, забезпечує раннє виживання після операції та швидшу гемодинамічну стабільність порівняно 3 хірургічним анастомозом [3] або довготривалою інфузією ПГЕ1 [4].

Висновки. Перфорація клапана легеневої артерії з одномоментним стентуванням відкритої артеріальної протоки є ефективним і безпечним методом для оптимізації легеневого кровотоку в пацієнтів з АЛА 3 ІМШП з помірною гіпоплазією ПШ і дозволяє уникнути хірургічного втручання (накладання модифікованого анастомозу Блелок-Тауссіг) або довготривалої інфузії ПГЕ1 в умовах відділення інтенсивної терапії.

\section{Література}

1. Alwi M. Management algorithm in pulmonary atresia with intact ventricular septum // Catheter Cardiovasc Interv. 2006. - Vol. 67. - P. 679-86.
2. Comparison of Ductal Stenting Versus Surgical Shunts for Palliation of Patients With Pulmonary Atresia and Intact Ventricular Septum / Kiran Mallula, Gabrielle Vaughn, Howaida El-Said et al. // Catheter CardiovascInterv. 2015. - Vol. 85 (7). - P. 1196-202. doi: 10.1002/ccd.25870.

3. Duct Stenting Versus Modified Blalock-Taussig Shunt in Neonates With Duct-Dependent Pulmonary Blood Flow: Associations With Clinical Outcomes in a Multicenter National Study / James R. Bentham, Ngoni K. Zava, Wendy J. Harrison et al. //Circulation. - 2018. - Vol. 137. - P. 581588. doi: 10.1161/CIRCULATIONAHA.117.028972.

4. Ductus Arteriosus Patency With Stenting in CriticalPulmonary Stenosis and Pulmonary AtresiaWith Intact Interventricular Septum / Carlos Mortera, Miquel Rissech, Joaquim Bartrons et al. // Rev EspCardiol. 2005. - Vol. 58 (5). - P. 592-5.

5. More Than 25 Years of Experience in ManagingPulmonary Atresia With Intact Ventricular Septum / Adriaan W. Schneider, Nico A. Blom, Eline F. Bruggemans et al. // Ann ThoracSurg. - 2014. - Vol. 98. - P. 1680-6.

6. Transcatheter pulmonary valve perforation using chronic total occlusion wire in pulmonary atresia with intact ventricular septum / Shweta Bakhru, Shilpa Marathe, Manish Saxena et al. // Annals of Pediatric Cardiology. 2017. - Vol. 10 (1). - P. 5-10.

\title{
The first experience of pulmonary valve perforation with concomitant arterial duct stenting in patients with pulmonary atresia and intact interventricular septum
}

\author{
Maksymenko A. V., Kuzmenko Y. L., Dovhaliuk A. A., Motrechko O. O., Vitovska O. R. \\ Ukrainian Children's Cardiac Center (Kyiv)
}

Pulmonary atresia with intact interventricular septum (PAIVS) - is a complex congenital heart disease characterized by a valve atresia with attendant right ventricle (RV) and a tricuspid valve (TV) hypoplasia of varying degrees with duct-dependent pulmonary circulation. One of the modern methods of treating PAIVS is pulmonary valve perforation with subsequent arterial duct stenting.

Purpose - to present first experience of the PV perforation with concomitant arterial duct stenting in patients with PAIVS.

Materials and methods. Three neonates with PAIVS were performed concomitant PV perforation with arterial duct stenting in UCCC.

Results and discussion. The procedure was successful in three newborn patients with moderate RV hypoplasia with a membranous PV atresia with IVS. On average, after intervention, patients were in the ICU for 5 days, two of them needed ventilatory support, one - sympathomimetic support. The median length of hospital stay was 13 days. Postoperative complications were not observed. There was no early mortality.

Conclusions. PV perforation with concomitant arterial duct stenting is an effective and safe method for optimizing pulmonary circulation in patients with PAIVS with moderate RV hypoplasia.

Key words: pulmonary atresia, pulmonary valve perforation, arterial duct stenting.

\section{Первый опыт перфорации клапана легочной артерии с одномоментным стентированием артериального протока у пациентов с атрезией клапана легочной артерии и интактной межжелудочковой перегородкой}

\author{
Максименко А. В., Кузьменко Ю. Л., Довгалюк А. А., Мотречко О. О., Витовская О. Р. \\ ГУ «Научно-практический медицинский центр детской кардиологии и кардиохирургии МЗ Украины» (Киев)
}

Атрезия клапана легочной артерии с интактной межжелудочковой перегородкой (АЛА с ИМЖП) - комплексный врожденный порок сердца, характеризующийся атрезией клапана с сопутствующей гипоплазией правого желудочка (ПЖ) и трехстворчатого клапана разной степени выраженности с дуктус-зависимым легочным кровотоком. Одним из 
современных методов лечения этого порока является перфорация клапана легочной артерии с дальнейшим стентированием открытого артериального протока (ОАП).

Цель работы - представить первый опыт перфорации клапана ЛА с одномоментным стентированием ОАП у пациентов с АЛА и ИМЖП.

Материалы и методы. На базе ГУ «НПМЦДКК МЗ Украины» трем новорожденным с АЛА и ИМЖП была выполнена одномоментная перфорация клапана ЛА со стентированием ОАП.

Результаты и обсуждение. Процедура была успешно проведена трем новорожденным пациентам с умеренной гипоплазией ПЖ с мембранозной атрезией клапана ЛА с ИМЖП. В среднем после вмешательства пациенты находились в ОРИТ на протяжении 5 суток, двум из них была необходима ИВЛ, одному - симпатомиметическая поддержка. Пациенты выписаны в среднем на 13-е сутки. Послеоперационных осложнений не наблюдалось. Ранней летальности не было.

Выводы. Перфорация клапана ЛА с одномоментным стентированием ОАП - эффективный и безопасный метод для оптимизации легочного кровотока у пациентов с АЛА и ИМЖП с умеренной гипоплазией ПЖ.

Ключевые слова: атрезия легочной артерии, перфорачия клапана легочной артерии, стентирование ОАП. 